\title{
Nitrate leaching from high production forage crop sequences
}

\author{
M.H. BEARE, F. TABLEY, R. GILLESPIE, S. MALEY, \\ T. HARRISON-KIRK and J. DE RUITER \\ ${ }^{1}$ The New Zealand Institute for Plant \& Food Research Limited, Private Bag 4704, \\ Christchurch 8140, New Zealand \\ Mike.Beare@plantandfood.co.nz
}

\begin{abstract}
New Zealand pastoral industries have set a goal of producing $45 \mathrm{t} \mathrm{DM} /$ ha annually from supplementary feed crops. Achieving this will require high inputs of water and nutrients that may increase the risk of nitrate leaching. This research describes nitrate leaching losses from the first year of intensively managed forage crop sequences to identify mitigation options. For cut-andcarry crops, the highest annual nitrate leaching losses were from crop sequences starting with maize compared to kale or barley. While maize-based sequences had the highest production (30-32 t DM/ha) they also had the highest $\mathrm{N}$ leaching losses per $\mathrm{t}$ DM produced $(2.4 \mathrm{~kg}$ $\mathrm{N} / \mathrm{t} \mathrm{DM})$. The best performing sequence was barley/ oats/Italian ryegrass which produced $28 \mathrm{t} \mathrm{DM} /$ ha but leached $<1 \mathrm{~kg} \mathrm{~N} / \mathrm{t}$ DM produced. Based on plots treated with synthetic urine and treading, we calculated leaching losses of 70-124 kg N/ha from autumn grazed crops (forage rape or oats). In general, nitrate leaching losses were not closely linked to estimates of cumulative drainage or fertiliser $\mathrm{N}$ inputs but were strongly influenced by crop type, sowing date and additions of livestock urine.
\end{abstract}

Keywords: nitrogen, fertiliser, forage crops, livestock urine

\section{Introduction}

Meeting the productivity targets of the South Island dairy industry requires the production of supplementary feed crops to meet the growing demand of cows, particularly during winter. To this end, the New Zealand pastoral industries have set a goal of producing $45 \mathrm{t} \mathrm{DM} / \mathrm{ha} / \mathrm{yr}$ from supplementary feed crops. The industry has also set a target of reducing $\mathrm{N}$ leaching losses by $50 \%$ relative to baseline levels. Maximising the annual supplementary feed production on a given paddock requires the establishment of tight-fitting crop sequences that are based on seasonally-adapted crops with a high efficiency of light capture. However, meeting industries feed production targets will also require high inputs of water and nutrients that may increase the risk of $\mathrm{N}$ losses. This is a concern given that elevated concentrations of nitrate $\left(\mathrm{NO}_{3}^{-}\right)$have been measured in shallow ground water in the Canterbury Plains and other key agricultural regions of New
Zealand (Francis et al. 1999). The objective of this research was to quantify nitrate leaching losses from intensively managed high input, high production forage crops sequences using the Forage Crop Sequences Trial at Lincoln. This paper describes the results from the first year of this trial as the first step in identifying management practices that may help to mitigate $\mathrm{N}$ losses from high production forage crop systems.

\section{Methods}

\section{Trial design and establishment}

The Forage Crop Sequence Trial was established to investigate the potential to achieve $45 \mathrm{t} \mathrm{DM} / \mathrm{ha}$ of annual supplementary feed production from carefully managed high input forage crops grown in tight-fitting rotations. The trial was established on a Paparua silt loam soil (sand at $30-50 \mathrm{~cm}$ ) at Lincoln, New Zealand (Lat. $43^{\circ} 64$ 'S; Long. $172^{\circ} 45^{\prime} \mathrm{E}$ ). It comprised successive summer and winter crops grown in rotation over 2 years from 6 Oct 2007 to 5 Oct 2009. This paper reports results from the first year of the trial where a total of 6 crop sequences were compared (Table 1). The first crop in each sequence was either maize (Zea mays hybrid 'P39G12', Treatments 1-2), kale (Brassica oleracea cv 'Gruner', Treatments 3-4), or barley (Hordeum vulgare cv 'Salute', Treatments 5-6), each established in spring 2007. Following harvest of Table 1 Crop sequences established in year one of the Forage Crop Sequence Trial.

\begin{tabular}{|c|c|c|c|}
\hline \multicolumn{2}{|c|}{ Treatment } & \multicolumn{2}{|c|}{---- Crop Sequences ----- } \\
\hline No & ID & 1st Crop & 2nd Crop \\
\hline 1 & Mw & Maize $^{1}$ & Wheat ${ }^{4}$ (green chop) \\
\hline 2 & Mtb & Maize $^{1}$ & $\begin{array}{c}\text { Triticale }^{5}+\text { Faba } \\
\text { beans }^{6}\end{array}$ \\
\hline 3 & $\mathrm{Kw}$ & $\mathrm{Kale}^{2}$ & Wheat $^{4}$ (green chop) \\
\hline 4 & Ktb & $\mathrm{Kale}^{2}$ & $\begin{array}{c}\text { Triticale }^{5}+\text { Faba } \\
\text { beans }^{6}\end{array}$ \\
\hline 5 & Bro & Barely ${ }^{3}$ & $\begin{array}{c}\text { Forage rape } e^{7} \text { then } \\
\text { Oats }^{8}\end{array}$ \\
\hline 6 & Boi & Barely $^{3}$ & Oats $^{8}$ then Italian ${ }^{9}$ \\
\hline
\end{tabular}

Cultivars: Maize ${ }^{1}$ ('P39G12'), Kale ${ }^{2}$ (cv 'Grunner'), Barely ${ }^{3}$ (cv 'Salute'), Wheat ${ }^{4}$ (cv 'Morph'), Triticale (cv 'Crackerjack'), Faba beans ${ }^{6}$ (NZ variety), Forage rape $^{7}$ (cv 'Goliath'), Oats ${ }^{8}$ (cv 'Milton'), Italian' (cv 'Feast II'). 
the first crops, the treatments were split to give a full six treatments in the second phase of each sequence (autumn/winter 2008). Following harvest of the second crops the treatments were split again to give a total of 12 treatments in the third (spring-autumn 2008/09) and fourth (autumn/winter 2009) phase of each sequence (details not shown here). The crops selected for each sequence were designed to maximise dry matter (DM) production. The sequences based on maize (treatments 1-2) or kale (treatments 3-4) were established primarily for use as cut-and-carry crops. The sequences based on barley (treatments 5-6) included crops suitable for grazing (rape, oats, multi-graze triticale) in addition to the barley which was grown for whole crop silage.

During the first and second phase of each sequence the plots were $46 \times 20 \mathrm{~m}$, each replicated 4 times. The trial was established in a split-plot design with main plots arranged in latinised blocks and with complete replication for all crop sequences. It was composed of two $300 \times 50 \mathrm{~m}$ columns each containing a balanced compliment of first and second crop treatments. Columns were designed to accommodate a lateral irrigator with a $50 \mathrm{~m}$ boom. Plots were separated by $8 \mathrm{~m}$ wide ryegrass buffer strips. The trial area was previously in lucerne (Medicago sativa) that was sprayed (Glyphosate + tribenuron methyl) on 31 July 2007. The area was ploughed on 7 September 2007 then rolled and lime applied at $2.5 \mathrm{t} / \mathrm{ha}$.

\section{Crop management}

Crops of barley (Hordeum vulgare cv 'Salute'), kale (Brassica oleracea cv 'Gruner') and maize (Zea mays hybrid 'P39G12') were sown on 23-25 October in the first phase (phase 1) of the crop sequences. Second (phase 2) crops of either wheat (Sirius, cv 'Morph') or triticale (cv 'Crackerjack') and faba beans (NZ variety) were sown (28 March-1 April 2008) into cultivated seedbeds following the maize (treatments 1-2) and kale (treatments 3-4) crops. Owing to the earlier harvest of barley, phase 2 crops of forage rape (cv 'Goliath') followed by oats (cv 'Milton', directdrilled) were sown in treatment 5 on 1 February and 19 May 2008, respectively. In treatment 6, barley was followed by oats (cv 'Milton') and Italian ryegrass (cv 'Feast II', direct-drilled) sown on 1 February and 15 May 2008, respectively. All crops were managed with optimum rates of $\mathrm{N}$ and irrigation applied to produce maximum crop yields. The type and rate of fertiliser applied to each crop is given in Table 2. Irrigation was applied to maintain soil water deficits in the top $1.5 \mathrm{~m}$ of the soil within the non-limiting range of crops. The deficit typically ranged from $0-80 \mathrm{~mm}$ but did approach values as high as $140 \mathrm{~mm}$ on selected dates (de Ruiter et al. 2009). These deficits suggest that summer crops were rarely under moisture stress assuming the plant available water capacity $(\mathrm{FC}[0.30 \mathrm{v} / \mathrm{v}]-\mathrm{WP}[0.08 \mathrm{v} / \mathrm{v}])$ to $1.5 \mathrm{~m}$ depth was $330 \mathrm{~mm}$. Further information on the crop management inputs for the phase 1 and 2 crops was reported by de Ruiter et al. (2009).

\section{Soil water and climate data}

Neutron probe access tubes were installed in all main plots shortly after crop emergence and soil moisture was monitored at $20 \mathrm{~cm}$ intervals down to $1.50 \mathrm{~m}$. Volumetric water deficits were calculated over the soil profile under each crop and used to adjust irrigation applications. Daily air and soil temperatures (LiCor 107 probes) and total incident radiation (LiCor 200 sensor) were recorded on site with Campbell loggers located adjacent to main crops of maize, kale and barley. Rainfall and irrigation were recorded with a $0.2 \mathrm{~mm}$ tipping bucket gauge located at the trial site. Detailed

Table 2 Type and rate of fertiliser applied to each of the first and second crops grown in the sequences.

\begin{tabular}{|c|c|c|c|}
\hline Crops & Fertiliser at sowing & $\begin{array}{l}\text { Side dressings } \\
\text { (kg N/ha) }\end{array}$ & Total $\mathrm{N}$ applied (kg N/ha) \\
\hline \multicolumn{4}{|l|}{ Summer crops } \\
\hline Maize & 300 kg/ha Nitrophoska & 125 (Urea) & 211 \\
\hline Kale & $\begin{array}{l}300 \mathrm{~kg} / \mathrm{ha} \text { DAP } \\
15 \mathrm{~kg} / \mathrm{ha} \text { Boronate }\end{array}$ & 250 (Urea) & 282 \\
\hline Barley & 150 kg/ha Cropmaster 15 & $2 \times 50$ (Urea) & 123 \\
\hline \multicolumn{4}{|c|}{ Autumn/winter crops } \\
\hline Wheat & 200 kg/ha CropZeal20N & None & 39 \\
\hline $\begin{array}{l}\text { Triticale }+ \\
\text { faba beans }\end{array}$ & 200 kg/ha CropZeal20N & None & 39 \\
\hline Rape then Oats & $\begin{array}{l}200 \text { kg/ha CropZeal20N } \\
15 \mathrm{~kg} / \text { ha Boronate }\end{array}$ & $\begin{array}{l}100 \text { (Urea) } \\
50 \text { (Urea) }\end{array}$ & 219 \\
\hline $\begin{array}{l}\text { Oats then } \\
\text { Italian ryegrass }\end{array}$ & 200 kg/ha CropZeal20N & $2 \times 100$ (Urea) & 129 \\
\hline
\end{tabular}


information on the climate (rainfall, temperature, radiation, Penman ET), soil water deficits and irrigation management at the site have been reported by de Ruiter et al. (2009).

\section{Crop performance and soil fertility data}

The DM production of all crops was measured through the season and at crop maturity before harvest. Details of the crop performance measurements are reported in de Ruiter et al. $(2009 ; 2010)$. The results of MAF Q-test analyses $(0-15 \mathrm{~cm}$ depth) made on 12 September (after cultivation) were $\mathrm{pH}$ 5.9, Ca 8, Olsen $\mathrm{P} 14, \mathrm{~K} 9$, $\mathrm{S}\left(\mathrm{SO}_{4}\right) 5, \mathrm{Mg} 7$, and $\mathrm{Na} 7$. Mineral $\mathrm{N}(2 \mathrm{M} \mathrm{KCl}$; Keeney $\&$ Nelson 1982) concentrations were determined from soil cores collected at $0-20,20-40,40-60,60-90,90-$ 120 , and $120-150 \mathrm{~cm}$ depths shortly before sowing (and fertiliser application) the summer and autumn/winter crops and following harvest of the autumn/winter crops.

\section{Nitrate Leaching}

Nitrate leaching was measured using soil solution samplers that were continuously monitored over the entire annual cycle of each crop sequence. Soil solution samples were collected from each of three samplers $(3.5 \mathrm{~cm} \mathrm{~d}$. PVC tubes equipped with porous ceramic tips) placed at depths of 0.60 and $1.50 \mathrm{~m}$ in each plot, whenever rainfall triggered a drainage event that exceeded $15 \mathrm{~mm}$. The amount of drainage was calculated using a water balance model based on measurements of soil moisture through the soil profile, daily rainfall, irrigation and evapotranspiration (Jamieson et al. 1995). The concentrations of nitrate $\left(\mathrm{NO}_{3}^{-}\right)$and ammonium $\left(\mathrm{NH}_{4}^{+}\right)$in the solution samples were analysed on a Foss FIAstar 5000 analyser.

\section{Urine treatment}

A single application of synthetic urine plus simulated treading was applied in the rape/oats and oats/ryegrass treatments in early May 2008 following the harvest of the forage rape (Bro, treatment 5) and oat (Boi, treatment 6) crops and immediately before sowing the subsequent oat and Italian ryegrass crops, respectively. Two adjacent subplots (each $2 \times 2 \mathrm{~m}$ ) were established in each of the ex-barley plots to accommodate a urine treatment ("Urine", synthetic urine plus treading) and an untreated control ("Control", no treading, urine or fertiliser $\mathrm{N}$ applied). Comparisons were also made with the fertilised ("Fertilised") main plots that were not treated with urine or treading. Each subplot was equipped with soil solution samplers, located at $0.6 \mathrm{~m}$ and $1.5 \mathrm{~m}$ depths, and a neutron probe tube positioned between the two subplots. The urine treatment was imposed by first mowing the plots to a height of about $5 \mathrm{~cm}$. Treading was then simulated by impacting the soil surface with a steel slide hammer device to apply approximately $220 \mathrm{kPa}$ of pressure to the soil surface, representing the treading impact of an adult Friesian cow (Di et al. 2001). Synthetic urine (recipe following Clough et al. 1998) was then uniformly applied to trodden plot using a watering can at a rate of $800 \mathrm{~kg}$ $\mathrm{N} /$ ha.

Figure 1 Nitrate concentrations in the soil profile to a depth of $1.5 \mathrm{~m}$ following harvest of the A) first (Barley, Kale or Maize) and B) second (Oats/ryegrass, Forage rape/oats, Wheat, or Triticale/faba beans) crops in the forage crop sequences. Bars are LSD (0.05) for comparing treatment means within depth.

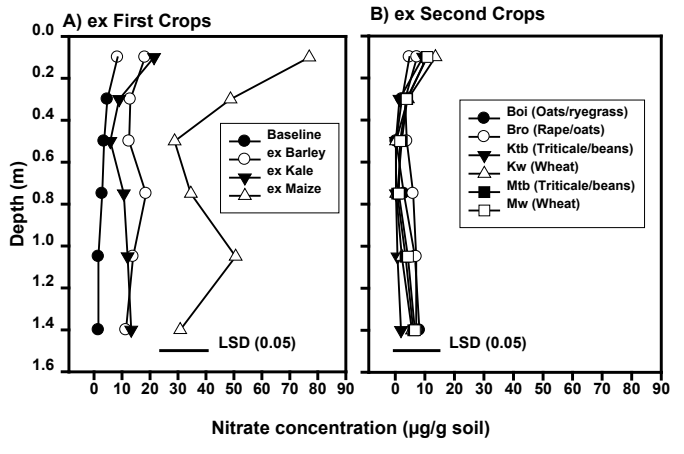

Table 3 Total fertiliser $\mathrm{N}$ applied, drainage and $\mathrm{NO}_{3}{ }^{-}$leached from each of the six forage crop sequences grown in year 1 .

\begin{tabular}{lccccc}
\hline & Nitrogen Fertiliser \\
Crop Sequence & $\begin{array}{c}\text { Drainage } \\
(\mathrm{mm})\end{array}$ & $\begin{array}{c}\mathrm{NO}_{3}^{-} \text {leached } \\
(\mathrm{kg} \mathrm{N} / \mathrm{ha})\end{array}$ & $\begin{array}{c}\text { Drainage } \\
(\mathrm{mm})\end{array}$ & $\begin{array}{c}\mathrm{NO}_{3}^{-} \text {leached } \\
(\mathrm{kg} \mathrm{N} / \mathrm{ha})\end{array}$ \\
\hline Barley/Rape/Oats (Bro) & 342 & 287 & 43 & 255 & 15 \\
Barley/Oats/Ryegrass (Boi) & 252 & 330 & 26 & 258 & 31 \\
Kale/Wheat (Kw) & 321 & 325 & 79 & 266 & 34 \\
Kale/Triticale+bean (Ktb) & 321 & 306 & 40 & 256 & 28 \\
Maize/Wheat (Mw) & 250 & 340 & 73 & 260 & 53 \\
Maize/Triticale+bean (Mtb) & 250 & 345 & 77 & 277 & 53 \\
LSD (0.05) & & 52 & 31 & & 57 \\
\hline
\end{tabular}




\section{Statistical Analysis}

Treatment effects were analysed by ANOVA and differences between treatment means evaluated by Least Significant Differences (LSD) at the 5\% level. Data were analysed using GenStat version 12.

\section{Results and Discussion}

The average total biomass production of summer crops was 23.2, 21.3 and $16.4 \mathrm{t} \mathrm{DM} / \mathrm{ha}$ for maize, kale and barley, respectively. Other crop performance information has been reported by de Ruiter et al. (2009). The total crop water use by maize, kale and barley was 659,650 and $398 \mathrm{~mm}$, respectively. However, owing to differences in soil water deficits imposed by the crops over time in association with differences in crop growth rates and duration (de Ruiter et al. 2009), the drainage

Table 4 Total dry mater production and the amount of nitrate leached per unit of dry matter produced from each of the six forage crop sequences grown in year 1 .

\begin{tabular}{lccc}
\hline & \multicolumn{3}{c}{$\begin{array}{c}\mathrm{NO}_{3}^{-} \text {leached per unit } \\
\text { of Dry Matter }\end{array}$} \\
\hline Crop Sequence & $\begin{array}{c}\text { Total Dry } \\
\text { Matter } \\
\text { (t/ha) }\end{array}$ & $\begin{array}{c}0.6 \mathrm{~m} \\
\text { depth } \\
(\mathrm{kg} \mathrm{N} / \mathrm{t} \\
\mathrm{DM})\end{array}$ & $\begin{array}{c}1.5 \mathrm{~m} \\
\mathrm{depth} \\
(\mathrm{kg} \mathrm{N} / \mathrm{t} \\
\mathrm{DM})\end{array}$ \\
\hline Barley/Rape/Oats (Bro) & 24.0 & 1.8 & 0.6 \\
Barley/Oats/Ryegrass (Boi) & 28.1 & 0.9 & 1.1 \\
Kale/Wheat (Kw) & 24.4 & 3.2 & 1.4 \\
Kale/Triticale+bean (Ktb) & 26.1 & 1.5 & 1.1 \\
Maize/Wheat (Mw) & 30.0 & 2.4 & 1.8 \\
Maize/Triticale+bean (Mtb) & 32.5 & 2.4 & 1.6 \\
\hline
\end{tabular}

of water from the top $0.6 \mathrm{~m}$ of soil under maize (93 $\mathrm{mm})$ and kale $(72 \mathrm{~mm})$ was considerably higher than that of the earlier harvested barley crop $(24 \mathrm{~mm})$.

Nitrate leaching losses from the summer crops at 0.6 $\mathrm{m}$ depth were low but significantly different $(\mathrm{P}<0.05)$, ranging from near zero losses under barley to 10 and $25 \mathrm{~kg} \mathrm{~N} / \mathrm{ha}$ under kale and maize, respectively (data not shown). The $\mathrm{NO}_{3}^{-}$leached under maize and kale crops at this depth was primarily associated with two drainage events where heavy rainfall followed a recent irrigation application. The difference in the $\mathrm{NO}_{3}^{-}$ leached from all three crops was more consistent with differences in drainage than fertiliser $\mathrm{N}$ inputs, though a full interpretation of these results requires a detailed $\mathrm{N}$ budget over time (i.e. during crop development) that is beyond the scope of this paper. Very low levels of $\mathrm{NO}_{3}{ }^{-}$ leaching ( 0.5 to $6 \mathrm{~kg} \mathrm{~N} / \mathrm{ha}$ ) were also recorded under the summer crops at $1.5 \mathrm{~m}$ depth though these losses are most likely associated with mineral $\mathrm{N}$ that was in the soil profile at the time the first crops were sown.

Despite low levels of nitrate leaching from the first crops, there were differences in the concentration of $\mathrm{NO}_{3}^{-}$remaining in the soil profile following their harvest that were consistent with the differences in $\mathrm{NO}_{3}^{-}$leached from the first crops (Fig. 1). Nitrate concentrations following barley and kale ranged from about $20 \mu \mathrm{g} \mathrm{N} / \mathrm{g}$ in the top $20 \mathrm{~cm}$ to about $12 \mu \mathrm{g} \mathrm{N} / \mathrm{g}$ at the $1.2-1.5 \mathrm{~m}$ depth. On average, these concentrations were only about $10 \mu \mathrm{g} \mathrm{N} / \mathrm{g}$ higher than the levels measured before the establishment of the crops in October (baseline). In contrast, nitrate concentrations following the maize crops ranged from about $75 \mu \mathrm{g} \mathrm{N} / \mathrm{g}$ in the top $20 \mathrm{~cm}$ to as low as $30 \mu \mathrm{g} \mathrm{N} / \mathrm{g}$ at $1.2-1.5 \mathrm{~m}$ depth. There was a significant $\mathrm{NO}_{3}^{-}$bulge at the 0.9-1.2 $\mathrm{m}$ depth where concentrations exceeded $50 \mu \mathrm{g} \mathrm{N} / \mathrm{g}$. As

Table 5 Effects of synthetic urine amendments on the drainage and $\mathrm{NO}_{3}^{-}-\mathrm{N}$ leached from each of the second crops in the exbarley forage crop sequences.

\begin{tabular}{|c|c|c|c|c|c|}
\hline \multirow[b]{2}{*}{$\begin{array}{l}\text { Crop }^{1} \\
\quad \text { Treatments }\end{array}$} & \multirow[b]{2}{*}{$\begin{array}{l}\text { N Applied } \\
\text { (kg/N ha) }\end{array}$} & \multicolumn{2}{|c|}{------------ 0.6 m ------------- } & \multicolumn{2}{|c|}{-------------- 1.5 m ----------------- } \\
\hline & & $\begin{array}{l}\text { Drainage } \\
(\mathrm{mm})^{1}\end{array}$ & $\begin{array}{c}\mathrm{NO}_{3} \text { Leached }(\mathrm{kg} \\
\mathrm{N} / \mathrm{ha})\end{array}$ & $\begin{array}{l}\text { Drainage } \\
(\mathrm{mm})\end{array}$ & $\begin{array}{c}\mathrm{NO}_{3} \text { Leached } \\
(\mathrm{kg} \mathrm{N} / \mathrm{ha})\end{array}$ \\
\hline \multicolumn{6}{|c|}{ Rape/Oats (Bro) } \\
\hline Control & 0 & 220 & 43 & 190 & 14 \\
\hline Fertilised & 219 & 263 & 45 & 217 & 19 \\
\hline Urine & 800 & 220 & 134 & 190 & 21 \\
\hline \multicolumn{6}{|c|}{ Oats/Ryegrass (Boi) } \\
\hline Control & 0 & 238 & 15 & 200 & 30 \\
\hline Fertilised & 129 & 251 & 26 & 202 & 31 \\
\hline Urine & 800 & 238 & 368 & 200 & 59 \\
\hline LSD (0.05) & & 42 & 44 & 36 & 19 \\
\hline
\end{tabular}

${ }^{1}$ The drainage values reported for the Control and Urine treatment plots are based a shared set of neutron probe measurements in each plot. 
discussed below, this residual mineral $\mathrm{N}$ posed a risk to $\mathrm{NO}_{3}^{-}$leaching during the establishment of the second crops (wheat and triticale/faba beans) that followed maize.

Drainage and nitrate leaching losses under the autumn/ winter crops were much higher than those measured under the summer crops and the leaching losses were significantly affected by the previous summer crop $(\mathrm{P}<0.01)$. For this reason the results for the summer and autumn/winter crops were combined to investigate the effects of each forage crop sequence on drainage and $\mathrm{NO}_{3}^{-}$leaching losses (Table 3). In general, there were no significant effects of the crop sequences on the total drainage of water over the first year of cropping but there was a significant effect of measurement depth. On average, the drainage from $0.6 \mathrm{~m}$ depth under these crop sequences was $322 \mathrm{~mm}$ compared to about $262 \mathrm{~mm}$ at $1.5 \mathrm{~m}$ depth over the annual cycle.

Nitrate leaching losses from the forage crop sequences were significantly affected by the first and second crops grown, the depth of measurement and their interaction. Over the full annual cycle, the $\mathrm{NO}_{3}^{-}$leached from the maize-based sequences ( $\mathrm{Mw} \& \mathrm{Mtb})$ at $0.6 \mathrm{~m}$ depth (73-77 kg N/ha) was higher than all of the other crop sequences except where wheat followed kale $(\mathrm{Kw})$ (Table 3). Overall, the barley-based sequences had the lowest total $\mathrm{NO}_{3}^{-}$leaching losses from $0.6 \mathrm{~m}$ depth; the losses from Bro (43 kg N/ha) being slightly higher than the losses from Boi $(26 \mathrm{~kg} \mathrm{~N} / \mathrm{ha})$. The relatively low leaching losses from the barley-based sequences at this depth are most likely the result of higher water and $\mathrm{N}$ use owing to earlier establishment and higher DM production by the forage rape/oats (Bro, $7.5 \mathrm{t} \mathrm{DM} / \mathrm{ha}$ ) and oats/ryegrass (Boi, 11.6 t DM/ha) crops. For the kale-based sequences, the leaching losses from wheat (Kw, $79 \mathrm{~kg} \mathrm{~N} / \mathrm{ha}$ ) were much higher than the losses

Figure 2 Nitrate concentrations in the soil profile to a depth of $1.5 \mathrm{~m}$ following harvest of the A) Oats/ Italian ryegrass and B) Forage rape/Oats grown following summer barley. The treatments include plots receiving fertiliser $\mathrm{N}$, urine and unfertilised controls. Bars are LSD (0.05) for comparing treatment means within depth.

he A) Oats/Italian ryegrass and B) Forage rape/Oats grown following summer barley. The reatments include plots receiving fertiliser N, urine and unfertilised controls. Bars are LSD 0.05 ) for comparing treatment means within depth.
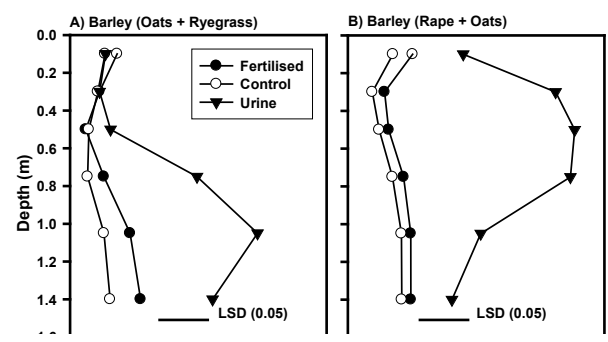

from triticale+faba beans (Ktb, $40 \mathrm{~kg} \mathrm{~N} / \mathrm{ha}$ ). In this case the triticale+faba beans established more rapidly than the wheat but their total DM production at harvest did not differ greatly ( $3.1 \mathrm{vs} 4.7 \mathrm{t} \mathrm{DM} / \mathrm{ha}$, respectively). The amount of $\mathrm{NO}_{3}^{-}$leached from $0.6 \mathrm{~m}$ under these crops did not correspond with differences in total drainage or fertiliser $\mathrm{N}$ inputs.

Despite similar amounts of drainage at $1.5 \mathrm{~m}$ depth, the average $\mathrm{NO}_{3}^{-}$leached from the maize-based sequences $(53 \mathrm{~kg} \mathrm{~N} / \mathrm{ha})$ were, on average, about 1.7 times those of the kale-based sequences $(31 \mathrm{~kg} \mathrm{~N} / \mathrm{ha})$ and 2.3 times those of the barley-based sequences (23 $\mathrm{kg} \mathrm{N} / \mathrm{ha}$ ) (Table 3). These losses are comparable to the estimated annual losses of 30-40 kg N/ha (Francis et al. 1999; de Klein \& Ledgard 2001) from typical dairy pastures (2.5-2.8 cows/ha; $50-60 \mathrm{~kg} /$ ha fertiliser $\mathrm{N})$ and measured annual losses of $20-75 \mathrm{~kg} \mathrm{~N} / \mathrm{ha}$ in the Waikato (Ledgard et al. 1999) and Southland (Monaghan et al. 2005). Leaching losses can vary substantially from year to year in relation to winter rainfall and distributions (Francis 1995). However, this variation may be reduced, and the total $\mathrm{NO}_{3}^{-}$leached increased, where irrigation is used to maintain lower soil water deficits.

The total DM production from the first and second crops grown in the forage crop sequence trial were reported previously by de Ruiter et al. (2009). Among the six crop sequences investigated in this study the maize-based sequences of Mw and Mtb had the highest total DM production, though these were followed closely by Bro and Ktb and the lowest DM production was recorded from the $\mathrm{Kw}$ and Bro sequences (Table 4). Although the maize-based ( $\mathrm{Mw} \& \mathrm{Mtb})$ sequences had the highest DM production, they also leached more nitrate per t DM produced $(2.4 \mathrm{~kg} \mathrm{~N} / \mathrm{t} \mathrm{DM})$ from the $0.6 \mathrm{~m}$ depth than all of the other crop sequences except where wheat followed kale (Kw, $3.2 \mathrm{~kg} \mathrm{~N} / \mathrm{t} \mathrm{DM}$ ). Overall, the best performing sequence was Boi which produced a total of $28 \mathrm{t} \mathrm{DM} / \mathrm{ha}$ but lost $<1 \mathrm{~kg} \mathrm{~N} / \mathrm{t} \mathrm{DM}$ produced over the entire annual cycle. Although the losses from $1.5 \mathrm{~m}$ depth were generally lower per t DM produced, similar differences were observed between the crop sequences; with the maize-based sequences having the highest average losses and the barley-based sequences having the lowest average losses per t DM produced.

The highest nitrate leaching losses were measured at $0.6 \mathrm{~m}$ depth under autumn/winter crops treated with synthetic urine and simulated treading (Table 5). Nitrate leaching losses from the $0.6 \mathrm{~m}$ depth were nearly 2-fold higher from the urine-treated plots under ryegrass (Boi, $368 \mathrm{~kg} \mathrm{~N} / \mathrm{ha}$ ) than under oats (Bro, 134 $\mathrm{kg} \mathrm{N} / \mathrm{ha}$ ). Leaching losses from the untreated control plots were only 5-32\% of the losses from the urine treatments and did not differ significantly from the 
fertilised treatments. Based on these measured losses, if we assume that approximately $30 \%$ of the soil surface area is exposed to urine when a forage crop is grazed, then the $\mathrm{NO}_{3}^{-}$leached from these autumn grazed crops would be expected to range between 70 and $124 \mathrm{~kg}$ $\mathrm{N} /$ ha. Interestingly, the $\mathrm{NO}_{3}^{-}$leached from $1.5 \mathrm{~m}$ depth was much lower than from the $0.6 \mathrm{~m}$ and was comparable to the losses measured at this depth under the other fertilised but ungrazed autumn/winter crops (e.g. $\mathrm{Mw} \& \mathrm{Mtb})$. The $\mathrm{NO}_{3}^{-}$leached from the urinetreated ryegrass plots (Boi, $59 \mathrm{~kg} \mathrm{~N} / \mathrm{ha}$ ) was nearly double that of the control and fertilised treatments but there were no significant effects of urine additions to the oat plots where the losses were much lower (Bro, 14$21 \mathrm{~kg} \mathrm{~N} / \mathrm{ha}$ ). The higher leaching loss from the urinetreated ryegrass (Boi) plots at $0.6 \mathrm{~m}$ was consistent with the high concentrations of $\mathrm{NO}_{3}^{-}$measured in the subsoil (0.6-1.5 m) following harvest of the crop (Fig. 2). In contrast, the $\mathrm{NO}_{3}^{-}$bulge recorded at $0.2-0.6 \mathrm{~m}$ depth in the urine-treated oat plots at crop harvest was consistent with the lower leaching loss measured from $0.6 \mathrm{~m}$ depth in this treatment. The high levels of residual $\mathrm{N}$ in the soil profile of the urine-treated plots following crop harvest may pose a risk for $\mathrm{NO}_{3}^{-}$leaching during the establishment of subsequent summer crops.

Autumn/winter grazed forage crops are a potentially large source of nitrate leaching losses from intensively managed crop sequences on well drained soils of Canterbury. The differences in nitrate leaching losses measured in this study were not closely linked to cumulative drainage or fertiliser $\mathrm{N}$ inputs and therefore imply that crop demand for $\mathrm{N}$ and the timing of sowing and grazing (i.e. urine applications) are important determinants of the nitrate leaching losses. Ongoing work seeks to identify crops and management practices that mitigate nitrate leaching losses from high production forage crop sequences.

\section{ACKNOWLEDGEMENTS}

We are grateful to Derek Wilson, Andrew Fletcher, Richard Sim, Mike George and Peg Gosden for their scientific and technical contributions. Funding was provided by two FRST contracts: Delivering Tools for Improved Environmental Performance (C10X0603) and Delivering Sustainable Forage Productivity Gains for NZ's Pastoral Industries (C10X0604), with supporting funds from DairyNZ, Fonterra, and Meat \& Wool NZ.

\section{REFERENCES}

Clough, T.J.; Ledgard, S.F.; Sprosen, M.S.; Kear, M.J. 1998. Fate of ${ }^{15} \mathrm{~N}$ labelled urine on four soil types. Plant and Soil 199: 195-203. de Klein, C.A.M.; Ledgard, S.F. 2001. An analysis of environmental and economic implications of nil and restricted grazing systems designed to reduce nitrate leaching from New Zealand dairy farms. I. Nitrogen losses. New Zealand Journal of Agricultural Research 44: 201-215.

de Ruiter, J.M.; Fletcher, A.; Maley, S.; Sim, R.; George, M. 2009. Aiming for $45 \mathrm{t} / \mathrm{ha}$ per annum: Yield of supplementary crops grown in sequences designed for maximum productivity. Proceedings of the New Zealand Grassland Association 71: 107-116.

de Ruiter, J.M.; Maley, S.; Chakwizira, E.; Fletcher, A. 2010. Determinants of productivity in cropping sequences for dairy systems in Canterbury, New Zealand. Proceedings of the Australian Society of Agronomy Conference (In press).

Di, H.; Cameron, K.C.; Milne, J.; Drewery, J.J.; Smith, N.P.; Hendry, T.; Moore, S.; Reijnen B. 2001. A mechanical hoof for simulating animal treading under controlled conditions. New Zealand Journal Agricultural Research 44: 111-116.

Francis, G.S. 1995. Management practices for minimising nitrate leaching after ploughing temporary leguminous pastures in Canterbury, New Zealand. Journal of Contaminant Hydrology 20: 313327.

Francis, G.S.; Webb, T.H.; Williams, P.H.; Bidwell, V.; Bright, J.; Close, M.E.; Jarvis, P.; Cameron, K.C.; Nuthall, P.; Scott, J. 1999. Implications of groundwater nitrate standards for agricultural management. Ecolink Project Report for MAF Policy. 149 pp.

Ledgard, S.F.; Penno, J.W.; Sprosen, M.S. 1999. Nitrogen inputs and losses from clover/grass pastures grazed by dairy cows, as affected by nitrogen fertilizer applications. Journal of Agricultural Science, Cambridge 129: 125-154.

Jamieson, P.D.; Francis, G.S.; Wilson, D.R.; Martin, R.J. 1995. Effects of water deficits on evapotranspiration from barley. Agricultural and Forest Meteorology 76: 41-58.

Keeney, D.R.; Nelson, D.W. 1982. Nitrogen - inorganic forms. pp. 643-698. In: Methods of Soil Analysis, Part 2, Second Edition. Ed. Page, A.L. Agronomy Society of America and Soil Science Society of America, Madison, Wisconsin.

Monaghan, R.M.; Paton, R.J.; Smith, L.C.; Drewry, J.J.; Littlejohn, R.P. 2005. The impacts of nitrogen fertilisation and increased stocking rate on pasture yield, soil physical condition and nutrient losses in drainage from a cattle-grazed pasture. New Zealand Journal of Agricultural Research 48: 227-240. 